\title{
Just when you thought you knew it all: new evidence for flexible breeding patterns in Continental Black-tailed Godwits
}

\author{
Nathan R. Senner ${ }^{1}$, Mo A. Verhoeven ${ }^{1}$, Jos C.E.W. Hooijmeijer ${ }^{1} \&$ Theunis Piersma $^{1,2}$ \\ ${ }^{1}$ Animal Ecology Group, Centre for Ecological and Evolutionary Studies, University of Groningen, P.O. Box 11103, \\ Groningen, The Netherlands, 9700 CC. n.r.senner@rug.nl \\ ${ }^{2}$ Department of Marine Ecology, NIOZ Royal Netherlands Institute for Sea Research, P.O. Box 59, 1790 AB Den Burg, \\ Texel, The Netherlands
}

Senner, N.R., Verhoeven, M.A., Hooijmeijer, J.C.E.W. \& Piersma, T. 2015. Just when you thought you knew it all: new evidence for flexible breeding patterns in Continental Black-tailed Godwits. Wader Study 122(1): 21-27.

Global climate change is rapidly altering the phenology and behaviour of species, leading to the occurrence of new and extreme trait values, especially among long-distance migratory birds. While infrequently published, the documentation and regular revision of the known spectrum of these trait values can be valuable for identifying the selective pressures acting on a population and influencing best management and conservation practices. Here we argue that the previously documented spectrum of reproductive behaviours in the rapidly declining Continental Black-tailed Godwit Limosa limosa limosa is in need of revision. Our data show that new extreme values for a number of reproductive traits occurred during the 2014 breeding season and that by almost every metric, 2014 had the longest laying period on record for the population. These findings suggest that godwit reproductive biology may be more flexible than previously thought and that this flexibility should be reflected by changes in European meadowbird policies.

\section{Keywords}

agri-environment schemes meadowbird conservation global climate change inter-annual variation adaptive management

\section{INTRODUCTION}

Determining the full spectrum of a species' or population's plasticity with respect to a trait - e.g. lay date, clutch size, or date of arrival on the breeding grounds - can help to identify their adaptive potential when responding to novel selection pressures. For instance, Liebezeit et al. (2014) recently documented that Arctic-breeding shorebird species have shifted the onset of their breeding season $0.4-0.8 \mathrm{~d}$ per-year earlier in response to increasingly early snowmelt. Identifying this shift was only possible with the documentation of the entire spectrum of lay dates for each population over the course of nine years. Regularly revising our knowledge of those trait values possible in a population can also affect conservation outcomes, as management objectives are often structured to accommodate the expected variation within a population. The durations of hunting seasons are a clear example: open seasons are frequently limited to those dates when portions of a population are expected to pass through an area (Myatt \& Krementz 2007). In general, it is important to document observations that challenge our knowledge of extreme values in these traits, especially when they can be incorporated into adaptive management models for populations threatened by environmental change.
Continental Black-tailed Godwits Limosa limosa limosa (hereafter, 'godwits') are one of the most well-studied and intensively managed bird populations breeding in W Europe. In-depth studies of their reproductive biology extend back to the middle of the 20th century (Balen 1959, Haverschmidt 1963, Klomp 1951, Mulder 1972, van Lind 1961) and more recent efforts have placed them at the centre of multiple demographic investigations (Beintema et al. 1985, Groen \& Hemerik 2002, Kentie et al. 2013a, Roodbergen et al. 2008, 2012, Schekkerman et al. 2009). Their dramatic decline over the past few decades (Gill et al. 2007) has also made godwits one of the focal species of meadowbird conservation policy throughout the European Union and the (indirect) recipient of billions of euros of agri-environmental subsidies (Groen et al. 2012, Kleijn et al. 2001, Kleijn et al. 2010, Verhulst et al. 2011). As a result, there is a significant body of received wisdom about godwit reproductive biology that directly influences our understanding both of the selection pressures contributing to the ability of godwits to respond to environmental change (Hooijmeijer et al. 2013, Kleijn et al. 2010, Schroeder et al. 2012) and the nature and implementation of EU agrienvironmental policy (Klimek et al. 2014, Overmars et al. 2014, Stoate et al. 2009). 


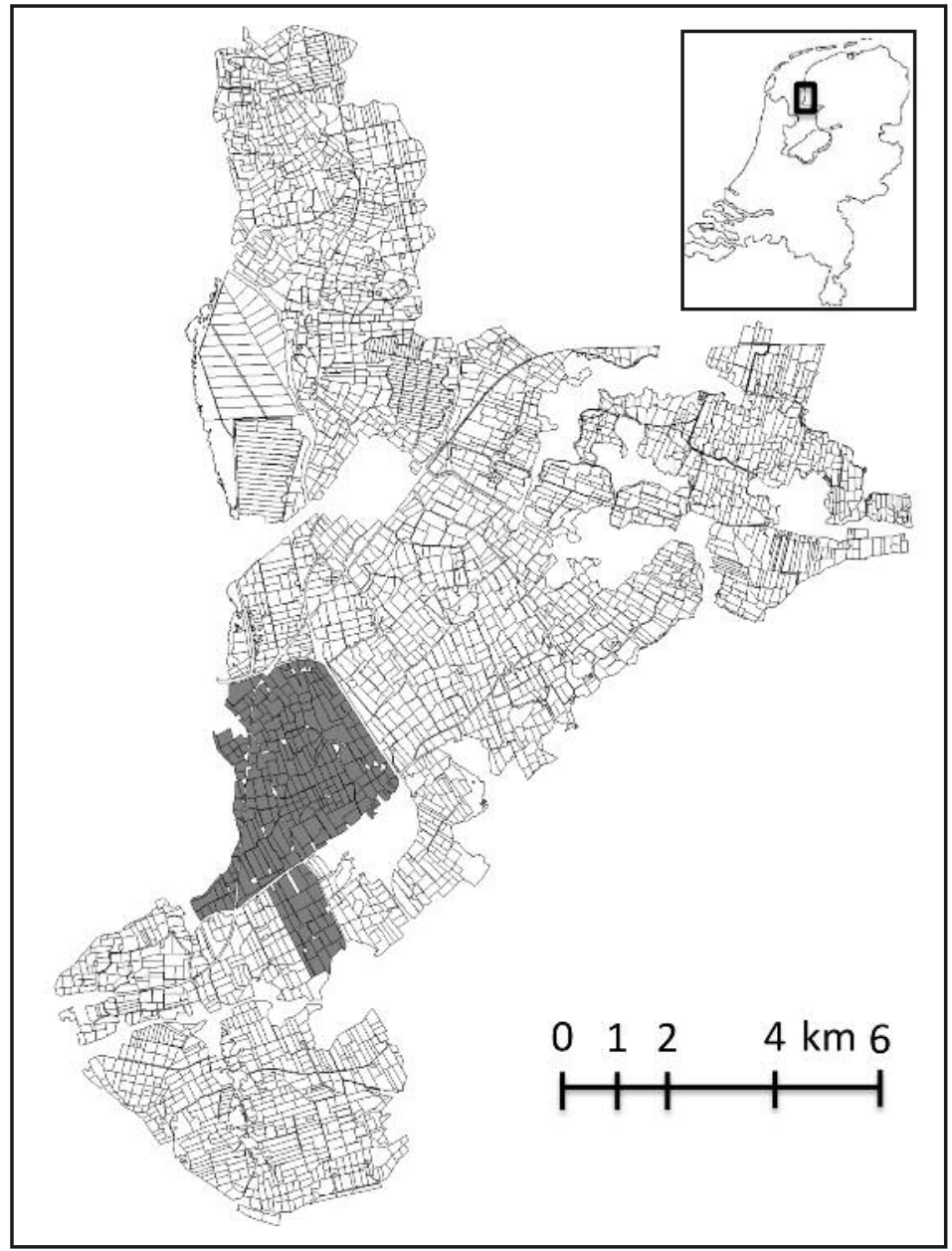

Fig. 1. Intensive and long-term demographic study areas of Black-tailed godwits Limosa limosa limosa in southwest Friesland, The Netherlands. The outlined area is the long-term demographic study area, while the dark grey area is the intensive study area begun in 2013. The inset displays the location of the study areas within The Netherlands.

\section{STUDY AREA AND METHODS}

During the 2013 and 2014 breeding seasons, we initiated an intensive study of godwit reproductive biology in the 112 -ha Haanmeer Nature Reserve $\left(52.9226^{\circ} \mathrm{N}, 5.4336^{\circ} \mathrm{E}\right)$ and surrounding eight polders ( $978 \mathrm{ha}$ ) in SW Friesland, The Netherlands (Fig. 1). This area was nested within our long-term godwit demographic study area, which comprises a total of 10,000 ha (cf. Kentie et al. 2013a, 2013 b 2014). Within our intensive study area we have made an effort to find every godwit nest and mark at least one breeding adult and all chicks at each nest. This effort has enabled us to monitor $184 \pm 44$ (mean \pm SD) nests, resight $251 \pm 2$ adults and mark $107 \pm 3$ adults and $337 \pm 6$ chicks in the Haanmeer in 2013 and 2014, a substantial increase over 2008-2012, when we found $67 \pm 13$ nests, resighted $72 \pm 39$ adults and marked $28 \pm 5$ adults and 80 \pm 28 chicks per year during less intensive studies in the same area. The intensive nature of our project and its connection to the larger-scale demographic study thus provides a unique opportunity to detail the full spectrum of godwit reproductive behaviours.

\section{OBSERVATIONS IN 2014}

The second year of our study, 2014, followed a record warm winter with mean annual temperature $2^{\circ} \mathrm{C}$ and precipitation $40 \mathrm{~mm}$ above the 40 -year average (Royal Dutch Meteorological Institute 2014). In this year, our field efforts documented a number of examples of godwit reproductive behaviour that fall outside of previously recorded extremes for this species from both the published literature and our own long-term study. These include: a renesting attempt after chicks were hatched, but lost to predation (1st nest, 14 April-13 May; 2nd nest, 21 May-15 June); a third nesting attempt after two previous nests had been lost to agriculture-related failure (1st nest, 14-15 April; 2nd nest, 17-27 April; 3rd nest, 19 May-12 June); a 31-d period between the initiation of the 10th and 90th percentile nests (15 April-16 May; $n=215$; Fig. 2); the initiation of $6.9 \%$ of all nests after 20 May $(n=215$; Fig. 3), leading to a total laying period duration of $57 \mathrm{~d}$ (8 April-4 June); and the record late initiation of a nest (4 June). However, despite the relatively high temperatures, nests were not initiated earlier in the season than 


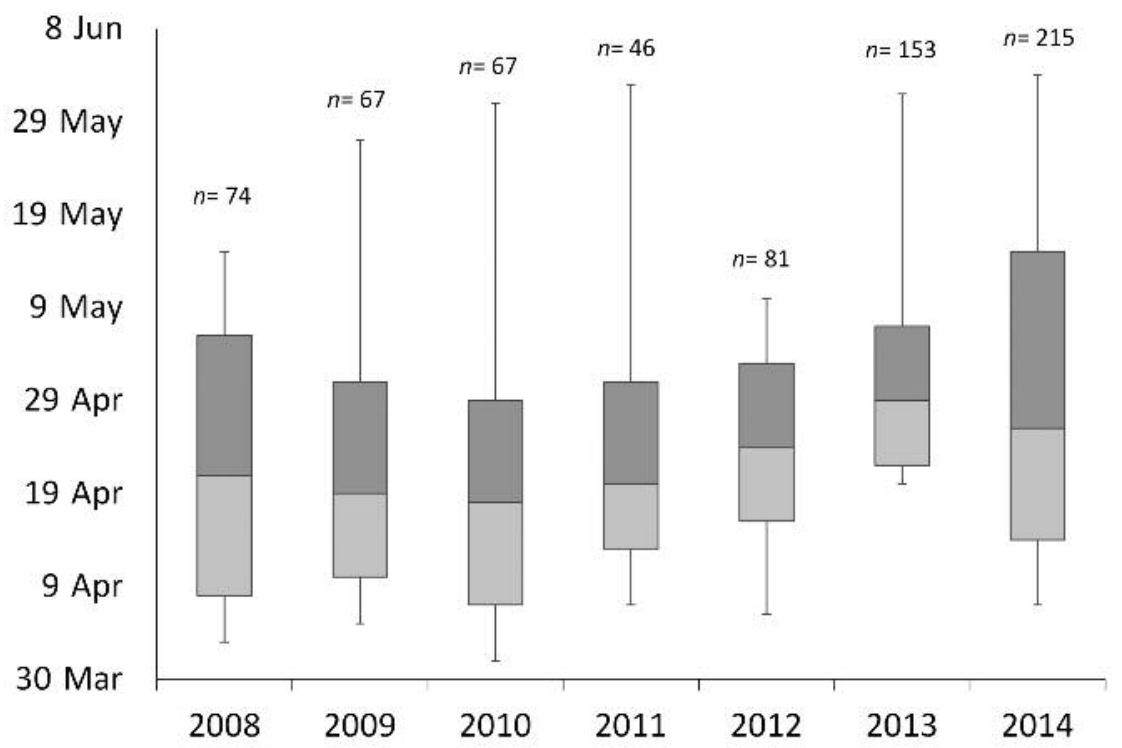

Fig. 2. Duration of Continental Black-tailed Godwit Limosa limosa limosa laying period in the Haanmeer Nature Reserve and surrounding polders, southwest Friesland, The Netherlands 2008-2014. Only those nests for which initiation dates could be determined were included. Bars indicate the 10th-90th percentiles of lay dates; the horizontal line, mean lay date; and vertical lines, the entire spectrum of lay dates. Nest searching effort increased during the 2013 and 2014 breeding seasons.

had been previously documented ( 1 st lay date = 8 April; Schroeder et al. 2012).

\section{DISCUSSION}

No Black-tailed Godwit study has previously documented a renesting attempt after the loss of chicks (Hooijmeijer et al. 2013, Schekkerman \& Müskens 2000). Similarly, although van Balen (1959) experimentally induced godwits to lay a third clutch (25\% of all destroyed 2 nd nesting attempts renested, $n=12$ ), no previous study had documented a naturally occurring third nesting attempt. Previously published studies had also documented earlier dates for latest clutch initiation (range $=18-30$ May), meaning shorter overall laying periods (range $=36-48 \mathrm{~d}$; Table 1 ). Likewise, in our study area prior to 2014, we documented a $20 \pm 5 \mathrm{~d}$ period between the initiation of the 10th and 90th percentile nests ( $n=6$; Fig. 2 ), a $48 \pm 10$ d overall

Table 1. The timing and duration of Black-tailed Godwit Limosa limosa limosa breeding seasons in The Netherlands 1953-2014. All blank cells indicate that no data were available in the published study. Only those studies for which data related to at least two of the variables displayed here were included. Averages across years are presented \pm SD.

\begin{tabular}{|c|c|c|c|c|c|c|c|}
\hline Study & Years & $\begin{array}{l}\text { Latitude \& } \\
\text { Longitude }\end{array}$ & $\begin{array}{c}\# \\
\text { Nests }\end{array}$ & $\begin{array}{c}\text { Earliest } \\
\text { Egg }\end{array}$ & $\begin{array}{l}\text { Median } \\
\text { Lay Date }\end{array}$ & $\begin{array}{l}\text { Latest } \\
\text { Egg }\end{array}$ & $\begin{array}{l}\text { Average } \\
\text { Duration }\end{array}$ \\
\hline van Balen (1959) & 1953-1954 & $52.2^{\circ} \mathrm{N}, 5.4^{\circ} \mathrm{E}$ & 30 & $14 \mathrm{Apr}$ & & 30 May & \\
\hline Beintema et al. (1995) & 1976-1985 & Netherlands & $>1,000$ & $18 \mathrm{Mar}$ & $17 \mathrm{Apr}$ & 27 May & \\
\hline Groen (1993) & 1984-1986 & $52.5^{\circ} \mathrm{N}, 4.8^{\circ} \mathrm{E}$ & 306 & & $21 \mathrm{Apr} \pm 3 \mathrm{~d}$ & 18 May & $40 \pm 1 d$ \\
\hline Kruk et al. (1996) & 1984-1991 & $52.1^{\circ} \mathrm{N}, 4.5^{\circ} \mathrm{E}$ & 686 & $18 \mathrm{Mar}$ & $11 \mathrm{Apr} \pm 7 \mathrm{~d}$ & 22 May & $36 \pm 16 d$ \\
\hline $\begin{array}{l}\text { Schekkerman \& } \\
\text { Beintema (2007) }\end{array}$ & 1993-1995 & $53.2^{\circ} \mathrm{N}, 5.3^{\circ} \mathrm{E}$ & 31 & 03 Apr & $15 \mathrm{Apr}$ & 25 May & \\
\hline $\begin{array}{l}\text { Roodbergen \& } \\
\text { Klok (2008) }\end{array}$ & 2002-2005 & $52.2^{\circ} \mathrm{N}, 4.6^{\circ} \mathrm{E}$ & 251 & $28 \mathrm{Mar}$ & $20 \mathrm{Apr} \pm 3 \mathrm{~d}$ & 26 May & $38 \pm 6 d$ \\
\hline This Study & 2008-2013 & $52.9^{\circ} \mathrm{N}, 5.4^{\circ} \mathrm{E}$ & 488 & $02 \mathrm{Apr}$ & $21 \mathrm{Apr} \pm 5 \mathrm{~d}$ & 03 Jun & $48 \pm 10 d$ \\
\hline This Study & 2014 & $52.9^{\circ} \mathrm{N}, 5.4^{\circ} \mathrm{E}$ & 215 & $08 \mathrm{Apr}$ & $23 \mathrm{Apr}$ & 04 Jun & $57 d$ \\
\hline
\end{tabular}




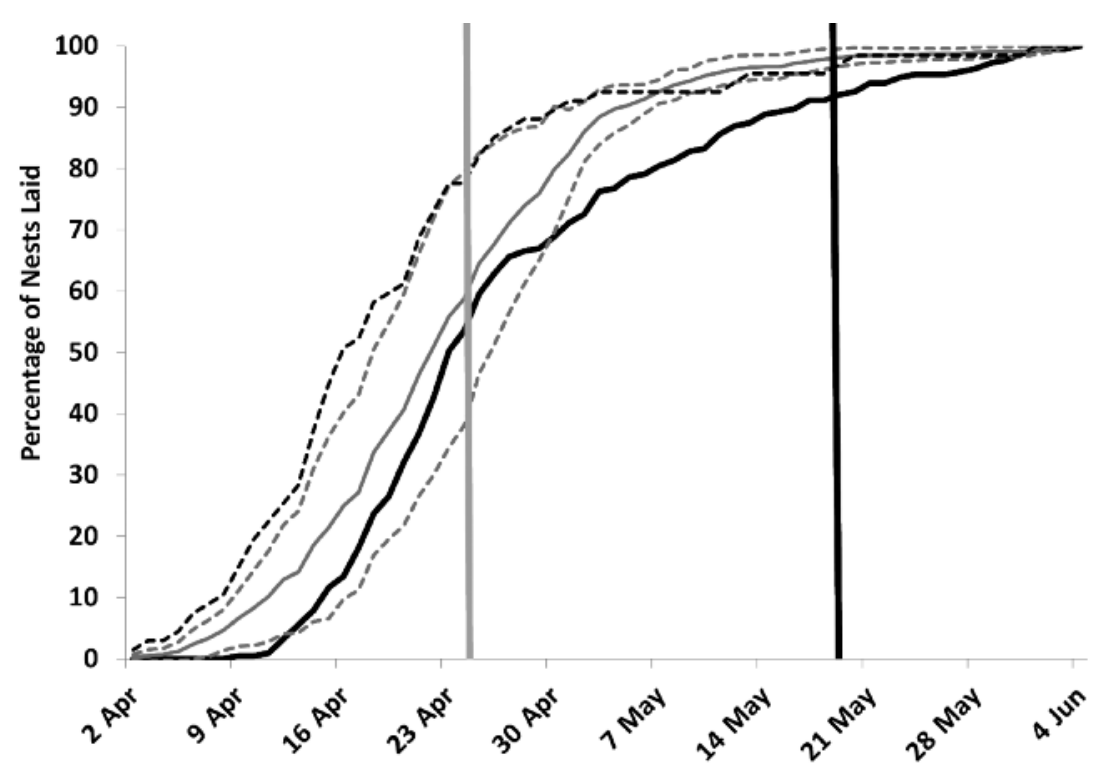

Fig. 3. Accumulation of Black-tailed Godwit Limosa limosa limosa nests by date in the Haanmeer Nature Reserve and surrounding polders, southwest Friesland, The Netherlands. The solid black curve represents the accumulation of nests by date in 2014; the dotted black curve 2011; the solid grey curve the average 2008-2012; and the dotted grey curves the $95 \%$ confidence interval for 2008-2012. Nests laid after the vertical grey line (25 April) will still have chicks on 15 June; nests laid after the vertical black line (20 May) will still have eggs on 15 June. Prior to 2014, 2011 was the year with the latest nest initiation date.

laying period $(n=6)$, the initiation of $1.41 \pm 1.37 \%$ of all nests after 20 May $(n=6$; Fig. 3), and a latest initiation date of 25 May $\pm 10 \mathrm{~d}(n=6)$.

The differences are particularly striking when comparing the results for 2014 with those obtained within our own intensive study area during 2013. Throughout the spring of 2013, The Netherlands, and indeed much of Europe, experienced record cold and unusually dry conditions (Royal Dutch Meteorological Institute 2014). The breeding season was, as a result, delayed and truncated (Senner et al. in review). Accordingly, in 2013, we documented only a 23-d period (23 April-8 May) between the initiation of the 10th and 90th percentile nests $(n=153)$, found only $3.6 \%$ of nests initiated after 20 May and observed an overall laying period duration of $45 \mathrm{~d}$ (19 April-2 June). Although 2013 was an abnormally cold season, these data are more similar to those found previously than to our findings from 2014 (Table 1, Figs. 2 \& 3).

What accounts for the differences in godwit reproductive behaviour between 2014 and those years covered by previous studies? The two years of our own study differed markedly in two important respects: First, the record cold and dry conditions which dominated the late winter and spring of 2013 (Royal Dutch Meteorological Institute 2014) raised energetic costs significantly for adult godwits, especially during the pre-breeding period (Senner et al. in review) and may have limited the ability of pairs to undertake second clutches after their first clutch failed (O’Brien \& Dawson 2013). Accordingly, we found only a $10 \%$ likelihood of renesting after a failed nest attempt in
2013 ( $n=10$ renests observed) in contrast to a $22 \%$ likelihood of renesting in $2014(n=41)$. Second, rates of nest loss due to predation and abandonment were lower in 2013 (apparent survival $=70.8 \%, n=153$ ) than in 2014 $(49.0 \%, n=215)$, possibly leading to a shorter overall laying period because fewer pairs were faced with the decision of whether or not to renest. In many respects, the first two years of our intensive study thus witnessed conditions at the extreme ends of the spectrum of those possible during spring and summer in The Netherlands.

The differences between 2013 and 2014 aside, however, it is unclear what has changed between this and previous studies. One possibility is that the observation of extreme trait values may be more likely when a study is carried out at a large scale. However, Teunissen et al. (2008) undertook their study on a truly large scale, comparing godwit reproductive behaviour among 12 agricultural areas spread across The Netherlands, with each averaging 281 ha. In total, they monitored 545 nests and radiotracked more than 130 adults. Similarly, over the course of our long-term demographic study, we have followed an average of 338 nests per season spread across an area that has ranged from 8,840 to 10,000 ha (Kentie 2015). Our intensive study in the Haanmeer does not approach the geographic scale of either of these projects. The level of effort in the Haanmeer, though, does equal and even surpass that of previous projects. For instance, in 2014, $59 \%$ of all nests in our intensive study area had at least one colour-marked adult $(n=215)$, as opposed to only $36 \%$ in the larger study area $(n=732)$. Such intensity may have allowed us to observe behaviours heretofore 
undocumented, although this seems unlikely given the sheer number of previous studies.

Ultimately, it may be that godwit reproductive behaviour is, in fact, changing. Warm, and especially wet, years can significantly lower the costs of incubation (Piersma et al. 2003), provide easier foraging conditions during the prebreeding period (Edwards \& Lofty 1982, Verhoeven et al. unpubl. data) and prolong the period of insect availability for chicks (Karlsson 2014, Roy \& Sparks 2000). These, in turn, can potentially enable female godwits to invest more in reproduction in a given year (de Heij et al. 2006, O'Brien \& Dawson 2013, Oro et al. 2014). Additionally, warm years may alter the set of cues used by godwits to demarcate their breeding season in unforeseen ways and lead to alterations in the timing of breeding through more complex mechanisms than simply energy availability (Camacho 2013, Flinks et al. 2008). As global climate change increasingly leads to warmer springs and summers, we should expect that the duration of godwit breeding seasons - and the likelihood that a pair will renest - may continue to change (Helm 2009).

Taken together, our new observations suggest that godwits may exhibit more flexibility in their reproductive behaviour than previously thought and demonstrates the potential for new extreme trait values to be recorded even for well-studied species, especially in conjunction with the increasing magnitude of climatic variation related to global climate change (Meehl \& Tebaldi 2004). Such knowledge is not merely of natural history interest, but also can be of considerable importance with respect to both identifying natural selection regimes and influencing meadowbird conservation policy. For example, in their analysis of godwit reproductive success, Schekkerman \& Müskens (2000) assume that godwits will not lay a second clutch after their first clutch has hatched, or lay a third clutch after two previous clutches failed. Our findings violate these assumptions, which may mean that this study, and subsequent publications citing it (e.g. Kentie et al. 2011, Roodbergen et al. 2008, 2012, Schekkerman et al. 2008, Teunnisen et al. 2008), could have underestimated the likelihood that a godwit pair will renest in a given season.

The fact that these studies directly influence meadowbird management practices raises the stakes of making such assumptions. In part because previous studies have found shorter godwit breeding seasons than those documented in our study, Dutch meadowbird policies assume that the godwit breeding season will be largely complete by 15 June, with the result that farmers receiving agri-environmental subsidies can begin mowing at this time (Netherlands Ministry of Agriculture, Nature and Food Quality 2010). Our observations suggest that such policies are likely to have a dramatic and negative impact on godwit reproductive success. For instance, in 2014, not only had 6.9\% of all nests not hatched prior to 15 June, but an additional $41 \%$ of all broods $(n=100)$ had not fledged by this date (Fig. 3); even in an average year in our study area, 35 $\pm 22 \%(n=6)$ of all nests would not have fledged by this date. These mowing practices therefore affect a significant proportion of the population in our study area on a regular basis. However, if godwits are more likely to renest and their breeding seasons last longer - than previously thought, the continuation of such a policy could greatly reduce the potential contribution of nests initiated late in the season and limit the overall ability of this rapidly declining species to respond to both global climate change and agricultural intensification. Given these potential ramifications, we urge a thorough and regular revision of the documented spectrum of important trait values for all species, but especially those of conservation concern.

\section{ACKNOWLEDGEMENTS}

We thank B. Brands, J. Gutiérrez, H. Hoekema, I. Lopez, A. McBride, M. Stager, H. van Kuik, J. Wiersma and L. Zwart, as well as the Grutto Field Crews 2008-2012, for their invaluable assistance in the field. A. Stokman, W. Nauta, S. Venema, Staatsbosbeheer and ANV Súdwesthoeke were very gracious in allowing us access to their land. R. Kentie, P. Smith and an anonymous reviewer provided valuable comments to an earlier draft of this manuscript. Funding for NRS, MAV and their fieldwork was supported by NWO-ALW TOP grant 'Shorebirds in space' (854.11.004) awarded to TP. The large-scale demographic study was supported by the Province of Fryslân, the Netherlands Ministry of Economic Affairs through the Kenniskring Weidevogellandschap and a grant from the van der Hucht de Beukelaar Stichting. TP and JCEWH were supported by institutional funding at $\mathrm{NIOZ}$ and the University of Groningen and by WWF-Netherlands and Birdlife International-Netherlands through the Chair in Global Flyway Ecology.

\section{REFERENCES}

Beintema, A.J., R.J. Beintema-Hietbrink \& G.J.D.M. Müskens. 1985. A shift in timing of breeding in meadow birds. Ardea 73: 83-89.

Beintema, A., O. Moedt \& D. Ellinger. 1995. Ecologische Atlas van de Nederlandse Weidevogels. Schuyt \& Co., Haarlem.

Camacho, C. 2013. Tropical phenology in temperate regions: extended breeding season in a long-distance migrant. Condor 115: 830-837.

de Heij, M.E., P.J. van den Hout \& J. Tinbergen. 2006. Fitness cost of incubation in Great Tits (Parus major) is related to clutch size. Proceedings of the Royal Society B 273: 23532361.

Edwards, C. \& J. Lofty. 1982. Nitrogenous fertilizers and earthworm populations in agricultural soils. Soil Biol. Biochem. 14: 515-521.

Flinks, H., B. Helm \& P. Rothery. 2008. Plasticity of moult and breeding schedules in migratory European Stonechats Saxicola rubicola. Ibis 150: 687-697.

Gill J.A., R.H.W. Langston, J.A. Alves, P.W. Atkinson, P. Bocher, N.C. Vieira, N.J. Crockford, G. Gelinaud, N. Groen, T.G. Gunnarsson, B. Hayhow, J. Hooijmeijer, R. 
Kentie, D. Kleijn, P.M. Lourenço, J.A. Masero, F. Meunier, P.M. Potts, M. Roodbergen, H. Schekkerman, J. Schroeder, E. Wymenga \& T. Piersma. 2007. Contrasting trends in two Black-tailed Godwit populations: a review of causes and recommendations. Wader Study Group Bulletin 114: 43-50.

Groen, N.M. 1993. De broedbiologie van de Grutto in een Noordhollands weidevogelreservaat. De Graspieper 13: 13-19.

Groen, N.M. \& L. Hemerik. 2002. Reproductive success and survival of Black-tailed Godwits Limosa limosa in a declining local population in the Netherlands. Ardea 90: 239-248.

Groen, N.M., R. Kentie, P. de Goeij, B. Verheijen, J.C.E.W. Hooijmeijer \& T. Piersma. 2012. A modern landscape ecology of Black-tailed Godwits: habitat selection in southwest Friesland, The Netherlands. Ardea 100: 19-28.

Haverschmidt, F. 1963. The black-tailed godwit. E.J. Brill, Leiden.

Hegyi, Z. 1996. Laying date, egg volumes and chick survival in Lapwing (Vanellus vanellus L.), Redshank (Tringa totanus L.), and Black-tailed Godwit (Limosa limosa L.). Ornis Hung. 6: 1-7.

Helm, B. 2009. Geographically distinct reproductive schedules in a changing world: costly implications in captive Stonechats. Int. Comp. Biol. 49: 563-579.

Hooijmeijer J.C.E.W., N.R. Senner, T.L. Tibbitts, R.L. Gill, Jr., D.C. Douglas, L.W. Bruinzeel, E. Wymenga \& T. Piersma. 2013. Post-breeding migration of Dutch-breeding Black-tailed Godwits: timing, routes, use of stopovers, and nonbreeding destinations. Ardea 101: 141-152.

Karlsson, B. 2014. Extended season for northern butterflies. Int. J. Biometeorol. 58: 691-701.

Kentie, R. 2015. Spatial demography of black-tailed godwits: metapopulation dynamics in a fragmented agricultural landscape. Thesis. University of Groningen. Groningen, The Netherlands.

Kentie, R., J. Hooijmeijer, C. Both \& T. Piersma. 2011. Grutto's in ruimte en tijd 2007-2010. Netherlands Ministry of Agriculture, Nature, and Food Quality, Den Haag.

Kentie, R., J.C.E.W. Hooijmeijer, K.B. Trimbos, N.M. Groen \& T. Piersma. 2013a. Intensified agricultural use of grasslands reduces growth and survival of precocial shorebird chicks. Journal of Applied Ecology 50: 243-251.

Kentie, R., J.C.E.W. Hooijmeijer \& T. Piersma. 2013 b. Grutto-demografie in Zuidwest Friesland vanaf 2004; update na de doorstart en uitbreiding in 2012. University of Groningen, Groningen, The Netherlands.

Kentie, R., C. Both, J.C.E.W. Hooijmeijer \& T. Piersma. 2014. Age-dependent dispersal and habitat choice in Black-tailed Godwits Limosa limosa limosa across a mosaic of traditional and modern grassland habitats. Journal of Avian Biology 45: 396-405.

Kleijn, D., F. Berendse, R. Smith \& N. Gillssen. 2001. Agrienvironment schemes do not effectively protect biodiversity in Dutch agricultural landscapes. Nature 413: 723-725.
Kleijn, D., H. Schekkerman, W.J. Dimmers, R.J.M. van Kats, D. Melman \& W.A. Teunissen. 2010. Adverse effects of agricultural intensification and climate change on breeding habitat quality of Black-tailed Godwits Limosa l. limosa in the Netherlands. Ibis 152: 475-486.

Klimek, S., G. Lohss \& D. Gabriel. 2014. Modelling the spatial distribution of species-rich farmland to identify priority areas for conservation actions. Biological Conservation 174: 65-74.

Klomp, H. 1951. Over de achteruitgang van de Kieviet, Vanellus vanellus in Nederland en gegevens over het legmechanisme en het eiproductievermogen. Ardea 39: 143-182.

Kruk, M., M.A.W. Noordervliet \& W.J. ter Keurs. 1996. Hatching dates of waders and mowing dates in intensively exploited grassland areas in different years. Biological Conservation 77: 213-218.

Liebezeit, J.R., K.E.B. Gurney, M. Budde, S. Zack \& D. Ward. 2014. Phenological advancement in arctic bird species: relative importance of snow melt and ecological factors. Polar Biology 10.1007/s00300-014-1522-x.

Lind, H. 1961. Studies of the behaviour of the black-tailed godwit (Limosa limosa). Munksgaard, Copenhagen.

Lourenço, P.M., R. Kentie, J. Schroeder, N.M. Groen, J.C.E.W. Hooijmeijer \& T. Piersma. 2011. Repeatable timing of northward departure, arrival and breeding in Black-tailed Godwits Limosa l. limosa, but no domino effects. Journal of Ornithology 152: 1023-1032.

Meehl, G.A. \& C. Tebaldi. 2004. More intense, more frequent, and longer lasting heat waves in the $21^{\text {st }}$ century. Science 305: 994-997.

Mulder, T. 1972. De Grutto in Nederland. Wetenschappelijke Mededeling KNNV. Hoogwoud, The Netherlands.

Myatt, N.A. \& D.G. Krementz. 2007. American Woodcock fall migration using central region band-recovery and wing-collection survey data. Journal of Wildlife Management 71: 336-344.

Netherlands Ministry of Agriculture, Nature and Food Quality.2010. https://mijn.rvo.nl/natuur (accessed 24 July 2014).

O’Brien, E.L. \& R.D. Dawson. 2013. Experimental dissociation of individual quality, food and timing of breeding effects on double-brooding in a migratory songbird. Oecologia 172: 689-699.

Oro, D., N. Hernández, L. Jover \& M. Genovart. 2014. From recruitment to senescence: food shapes the age-dependent pattern of breeding performance in a long-lived bird. Ecology 95: 446-457.

Overmars, K.P., C.J.E. Schulp, R. Alkemade, P.H. Verburg, A.J.A.M. Temme, N. Omtzigt \& J.H.J. Schaminée. 2014. Developing a methodology for a species-based and spatially explicit indicator of biodiversity on agricultural land in the EU. Ecological Indicators 37: 186-198.

Piersma, T., Å. Lindström, R.H. Drent, I. Tulp, J. Jukema, R.I.G. Morrison, J. Reneerkens, H. Schekkerman \& G.H. Visser. 2003. High daily energy expenditure of incubating shorebirds on High Arctic tundra: a circumpolar study. Functional Ecology 17: 356-362. 
Roodbergen, M. \& C. Klok. 2008. Timing of breeding and reproductive output in two Black-tailed Godwit Limosa limosa populations in The Netherlands. Ardea 96: 219232.

Roodbergen, M., C. Klok \& H. Schekkerman. 2008. The ongoing decline of the breeding population of Blacktailed Godwits Limosa l. limosa in The Netherlands is not explained by changes in adult survival. Ardea 96: 207-218.

Roodbergen, M., B. van der Werf \& H. Hötker. 2012. Revealing the contributions of reproduction and survival to the Europe-wide decline in meadow birds: review and meta-analysis. Journal of Ornithology 153: 53-74.

Roy, D.B. \& T.H. Sparks. 2000. Phenology of British butterflies and climate change. Global Change Biology 6: 407416.

Royal Dutch Meteorological Institute. 2014. www.knmi.nl (accessed 18 July 2014).

Schekkerman, H. \& G. Müskens. 2000. Produceren grutto's Limosa limosa in agrarisch grasland voldoende jongen voor een duurzame populatie? Limosa 73: 121134.

Schekkerman H., W. Teunissen \& E. Oosterveld. 2008. The effect of 'mosaic management' on the demography of Black-tailed Godwit Limosa limosa on farmland. Journal of Applied Ecology 45: 1067-1075.

Schekkerman, H., W. Teunissen \& E. Oosterveld. 2009. Mortality of Black-tailed Godwit Limosa limosa and Northern Lapwing Vanellus vanellus chicks in wet grass- lands: influence of predation and agriculture. Journal of Ornithology 150: 133-145.

Schroeder, J., T. Piersma, N.M. Groen, J.C.E.W. Hooijmeijer, R. Kentie, P.M. Lourenço, H. Schekkerman \& C. Both. 2012. Reproductive timing and investment in relation to spring warming and advancing agricultural schedules. Journal of Ornithology 153: 327-336.

Senner, N.R., M.A. Verhoeven, J.M. Abad-Gómez, J.S. Gutiérrez, J.C.E.W. Hooijmeijer, R. Kentie, T.L. Tibbitts \& T. Piersma. In review. When Siberia came to The Netherlands: the response of black-tailed godwits to a rare spring weather event. Journal of Animal Ecology.

Stoate, C., A. Báldi, P. Beja, N.D. Boatman, I. Herzon, A. van Doorn, G.R. de Snoo, L. Rakosy \& C. Ramwell. 2009. Ecological impacts of early $21^{\text {st }}$ century agricultural change in Europe - a review. Journal of Environmental Management 91: 22-46.

Teunissen, W., H. Schekkerman, F. Willems \& F. Majoor. 2008. Identifying predators of eggs and chicks of Lapwing Vanellus vanellus and Black-tailed Godwit Limosa limosa in the Netherlands and the importance of predation on wader reproductive output. Ibis 150: 74-85.

van Balen, J.H. 1959. Over de voortplanting van de Grutto, Limosa limosa L. Ardea 47: 76-86.

Verhulst, J., D. Kleijn, W. Loonen, F. Berendse \& C. Smit. 2011. Seasonal distribution of meadow birds in relation to in-field heterogeneity and management. Agriculture, Ecosystems \& Environment 142: 161-166. 